\title{
THE LUKAN DEFENSE OF THE MISSIONARY PRISONER PAUL ${ }^{1}$
}

\author{
Brian Mark Rapske
}

\section{Introduction}

In the book of Acts, two biographical facts concerning the apostle Paul loom very large: first, Paul was a missionary who pursued his calling with great vigour. By every measure one might wish to choose, Paul is singularly significant as a missionary in Lukan reckoning. Second, Paul was a prisoner quite frequently and for long periods of time. There is general agreement in the literature that Paul's moves from itinerant missionary to prisoner were neither easy nor without consequence. What is not remarked specifically or with any degree of completeness is the extent to which these two biographical facts did not stand alongside one another at all comfortably, the realms or dimensions within which difficulty occurred as a result, and how Luke wished his readers to relate the facts.

Imprisonment posed serious practical problems and stigmatised individuals in the ancient world and this would have been no less the case for Paul. An unfailing emphasis of the study was to locate the missionary Paul's experiences firmly within the Greco-Roman context. Luke, it was argued, was keenly aware that imprisonment constituted a serious assault upon both the missionary and his mission. The thesis prosecuted throughout the work was that, in the light of the known and multifarious crises that imprisonment brought upon Paul and his mission, one of Luke's objectives in Acts was to defend or justify the missionary prisoner Paul to the reader.

\footnotetext{
1B.M. Rapske, Pauline Imprisonment and the Lukan Defense of the Missionary Prisoner Paul in the Light of Greco-Roman Sources (Unpublished PhD Dissertation, University of Aberdeen 1992), supervisor: Professor I.H. Marshall.
} 


\section{Going Into Custody}

As with litigation in the courtroom, the process of going into custody shared in the general structure and ethos of ancient Mediterranean society -in particular, Roman society. 'Going to jail' was a legal and social process having ancient complexity and system to it. Custody was quite varied in its purposes and severity. In consequence, an accused person needed to be properly evaluated by a magistrate before a fair and appropriate custody could be set. This was done using institutionalised and acceptable means-by assessing the seriousness of the crime alleged, the status of accused, and the status of accuser. 'High' and 'low' status were determined by reference to the measures of one's citizen and social persona. The sinister forces of power, influence and bribery, while formally deemed unacceptable and punishable under the law, oftentimes intruded upon custodial deliberations, skewing them to the advantage or disadvantage of the various parties concerned.

It was argued that the apostle Paul in Acts is, in his citizen and social persona, an historically credible figure. His persona, however, was shot full with a status dissonance-i.e., 'high' status in some respects but 'low' in others-possessing explosive negative potential when the 'wrong' people were assessing him. It was further argued that disclosures of the Pauline persona were both strategy driven and constrained.

In descriptions highly sensitive to the process of setting custody and the Roman official concerns and interests which that process represented, Luke records for his readers how the apostle Paul ran into serious trouble time and again. The logic of the deliberative process helpfully illuminates many of the elements in the action which have inspired modern puzzlement and scepticism. The apparently 'un-Roman' citizenship disclosures of Paul at Philippi and Jerusalem and the supposedly irrelevant conversation between Lysias and Paul where citizenships are compared are noteworthy instances.

\section{The Privations of Life in Custody}

Modern assessments of the severity or ease of Paul's life in prison in Acts have lacked precision because there has been little if any systematic calibration of the apostle's experiences with descriptions in the ancient sources. First, custody frequently brought varied and terrible physical and emotional 
privations upon the prisoner and these were systematically surveyed and discussed. Second, hostility was the dominant and governing tone in keeper and inmate relations. Examples of helpfulness and humanity in relations were also to be found but these were exceptional. Such relations sprang from a number of different motives and these were specified. Finally, in a culture where social relations were extensively driven by honour and shame concerns, imprisonment and the wearing of bonds carried significant shame connotations. The social stigma was lasting or even lifelong and the pressure upon associates, friends, family and even co-religionists to abandon the prisoner to public disgrace was considerable.

Luke shows Paul in Acts experiencing many of the same physical rigours in custody as those discovered in the literature. While he indicates that Paul's custody is lightened at some places and that there are shining instances of favour toward the apostle, this hardly justifies the tendency of some to characterise the accounts of Paul's experiences in Acts as ideally drawn. Rather, in the alleged ideal descriptions, there are subtly-drawn and unmistakable indicators of physical distress and a climate of uncertainty and threat. Acts indicates both Paul's and the author's own deep sensitivities to shame and honour concerns and draws attention to various attempts to counteract the social damage and stigma associated with imprisonment and the wearing of bonds.

\section{Paul: A Missionary Prisoner}

In the face of such a massive negative impact-the damage of the process of going into custody, the rigours and constrictions of being in custody, and the shame/dishonour connections of being a prisoner-the question to be asked was, 'What did Luke do to counter the impression of disqualification and to demonstrate unequivocally Paul's continuing viability as a missionary?' It was argued that Luke defends the missionary prisoner Paul to his readers along three lines.

First, Luke is concerned to show that Paul continued, despite his being a prisoner in bonds, to be an effective missionary. As other Greek and Roman prisoners, Paul engaged in various personal pastimes and religious disciplines. The text and textual implications of Acts, however, leave no doubt in the reader's mind that beyond these, the prisoner Paul was also 
involved in a vigorous ministry of preaching, teaching and community direction. Particular attention might be drawn to Luke's description of Paul's ministry in Rome which would have been deemed to be in first century Christian reckoning, above all other images of ministry effectiveness, perhaps the most powerful and positive.

Second, Luke shows that various individuals demonstrate interest in and give support and assistance to the missionary prisoner Paul. A wide variety of sources outside of Acts helpfully structured and informed the discussion in this regard. Luke shows Christian co-workers 'covering' Paul with their status, a family member braving the dangerous prison environment of the Fortress Antonia to give a message, a newly-converted Philippian jailer taking great personal risks in assisting Paul and Silas, and assistance coming from sympathisers in Caesarea. Small congregations (as well as interested pagans!) hasten Paul along his way to Rome with varied expressions of love and consideration and even before he finally arrives, the Roman church embraces the missionary prisoner officially and at its highest levels of leadership.

Finally, Luke is at considerable pains to show that the missionary prisoner Paul is divinely approved. Inasmuch as Paul might protest that he was for the Lord, Christians and non-Christians alike might fairly ask, in the light of his being so often and so long a prisoner, 'Is the Lord for Paul?' Pagan and later Christian conceptions of the sense of being divinely commissioned to suffer as a prisoner as well as descriptions of direct divine assistance and assurance to prisoners were considered and compared with Lukan indications for the prisoner Paul. Luke undertakes to present to his readers a Paul who is both divinely anticipated (Lk. 21:14-19) and progressively more closely commissioned as a missionary prisoner (Acts 9:15f.; $19: 21 ; 20: 22-4 ; 21: 10-14)$. The three instances of direct divine assistance (Acts 16:26; 23:11; 27:23f., 26) assure and affirm Paul, validating and enhancing his ministry in custody; moreover, the two oracles at 23:11 and 27:23f. furnish Luke's readers with a tool by which Paul's prison troubles from chapter 21 to the end of Acts may properly be interpreted. By commission and by direct assistance and assurance, then, Luke indicates to his readers that the Lord is emphatically for the missionary prisoner Paul. 